\title{
EXPERIENCIE WITH ANTIGEN MARIANUM IN THE TREATMENT OF LEPROSY
}

\author{
A. L. RelviCH, M.D., D.P.H., D.T.M. \& H., \\ Medical Field Units, Western Region. Nigeria
}

Antigen Marianum has been prepared in the "Laboratoire de Recherche sur la Lepre " at Lyons. It is a dilution of a culture of Mycobacterium marianum isolated in that laboratory from a leproma. Blanc ( I953) has experimented with intradermal injections of this into healthy subjects and into patients with leprosy. He observed after three monthly injections a change from negative to positive Mitsuda reaction in 20 out of 29 lepromin negative " controls," 57 out of 90 patients with " indeterminate " type of leprosy and II out of 29 patients suffering from lepromatous leprosy. He has achieved even better results when he gave two series of injections. As many as 5I lepromin negative lepromatous patients out of $55(90 \%)$ became lepromin positive although curiously enough only ror out of $132(76 \%)$ " indeterminate" ones.

From these results Blanc derived the idea of a treatment of leprosy based on immunotherapy instead of chemotherapy. In the beginning he combined the injections of the antigen with sulphones but later the sulphones were omitted. Moreover he has applied this treatment not only to lepromin negative cases but to lepromin positive tuberculoid ones as well. According to him the improvement on this treatment was faster, more stable, and accompanied by fewer reactions than with sulphones.

In 1954 Sister Marie Suzanne, the Director of the I.yons laboratory, offered me a supply of the antigen for a clinical trial on my patients at Ossiomo settlement in Western Nigeria. The trial started in February, I955, on 49 patients admitted since the previous September. They were divided into two groups. One group was put on the antigen treatment, the other was kept as a control. All patients admitted to the Settlement subsequently until August, I955, were added to the trial, in all 63 in the treatment group and 63 as controls. As to the type of the disease among the treated patients, 33 were lepromatous, 27 tuberculoid and 3 dimorphous (indeterminate). Among the controls there were 26 lepromatous cases, 33 tuberculoid and 4 dimorphous.

In spite of the favourable results reported by Blanc, I was not prepared to go so far as to give the antigen as the only form of treatment to the patients. All patients continued their routine treatment with sulphones. 


\section{Method}

o.I $\mathrm{ml}$. of the antigen was injected once a month into the skin of the frontal aspect of each forearm alternatively for six months. Then followed a rest of 2 months, after which the injections were resumed.

The bacteriological examination was performed in the first instance by taking only one smear from the apparently most affected portion of the skin. The results of the test were classified into four categories: + I for less than Io bacilli in the field of vision under an immersion lens, +2 for I0-20 bacilli, +3 for 20-30 bacilli and +4 for more than 30 bacilli in the field. Later I decided to introduce a more exact evaluation by the use of a bacteriological index. The difference was that instead of taking one smear I took six and added the figures; so for instance if the classification based on the old system was +3 the expected index would be around I 8 . I used this index method in my first evaluation test in September, I955, and intended to use it in further periodical examinations.

At the end of September, I955, I proceeded on a long leave and the trial was stopped two months later. Consequently I can report here only on the results found by me in September, I955, after the patients had received between I- 6 months of the treatment, and the position in March, 1957, when I saw them again I6 months after the trial was stopped.

\section{General}

\section{Immediate Reaction to the Injection}

All patients had a rise in the temperature on the day following the injection. In about $25 \%$ of them the temperature rose above $100^{\circ} \mathrm{F}$. In the majority of patients the general reaction lasted only one day but in some it went on longer, up to one week. Following each injection one or two patients went into the erythema nodosum type of lepra reaction. The general reaction has been stronger in the lepromatous patients than in the tuberculoid. On the whole, the degree of the general reaction has been constant in individual patients after each injection.

\section{Local}

A few hours after the injection an inflammatory swelling about an inch in diameter developed at the site. By the next day a papule formed which changed into a nodule. Four or five days after the injection the nodule started to ulcerate. The ulceration remained for a few days and began healing about a week to ten days after the injection. The scar was still very obvious several months after 
the injection but after a year it was hardly visible. No tolerance to the injection was developed. Every consecutive injection brought the same general and local reaction.

\section{Change in the Sensitivity to Lepromin}

I performed the Mitsuda test with crude lepromin in I9 lepromin negative patients a month after the end of the first series of injections. I found that 4 patients had converted to a positive reaction, 2 to a weak positive reaction and 13 remained lepromin negative. Therefore my results were not as favourable as those of Blanc who had a conversion in $90 \%$ of his lepromatous patients after six injections of the antigen.

\section{Clinical and Bacteriological Findings}

The patients have been reviewed twice, in September, 1955, and in March, I957. By the time of the first review one lepromatous patient æt. 8 years had died of acute nephritis of unknown origin. Between the first and the second review 2 lepromatous and 5 tuberculoid patients of the treated ones, and 3 lepromatous and I tuberculoid among controls left the settlement. Therefore at my second review I was able to evaluate 30 lepromatous, 22 tuberculoid and 3 dimorphous treated cases, and 23 lepromatous, 32 tuberculoid and 4 dimorphous controls. These patients had received between four and eight injections of the antigen.

\section{Tuberculoid and Dimorphous Cases}

It is difficult to estimate improvement in bacteriologically negative cases of leprosy where one had to depend on findings which are to a certain extent subjective. Certainly there has been no significant difference in the progress between the patients who had been receiving the injections of the antigen and those receiving no antigen. Five tuberculoid patients who received the antigen were fit for discharge before my second review, but so were 6 tıberculoid and 2 dimorphous controls.

\section{Lepromatous Cases}

Here one can base the evaluation of the progress not only on clinical but also on objective bacteriological findings.

The first batch of patients, who have had eight injections of the antigen, are shown in Table I and their controls in Table II. I have tried to compare the results in these two groups by the following computation: I have multiplied the figures in the first column by six to obtain an approximate index comparable with the indices in the other two columns and then added the indices 
in each column. In this way I obtained the figures 216,170 and 77 for the treated patients and 138, I00 and 37 for the controls, showing actually slightly better results for the controls than for the treated patients $(75 \%$ improvement in the controls against $65 \%$ in the treated). However, due to rather imperfect matching of patients in the two groups, there was a lesser number of severe cases among the controls than among the treated. This might have affected the results.

The findings for the second batch of patients, who have had seven injections, and their controls are shown in Tables III and IV. Here the computation gives figures I26, $9 \mathrm{I}$ and $4 \mathrm{I}$ for treated patients and 36, 29 and 6 for the controls, again more favourable to the controls, but subject to the same criticism as the first batch.

The findings for the third, fourth and fifth batch, all of whom have had six injections of the antigen, and their controls, are presented in Tables $\mathrm{V}$ and VI. The additions give the figures 168, I52 and 81 for treated cases and I02, 93, and 52 for controls showing the same degree of improvement (about 50\%).

The sixth batch of patients, who have had five injections, and their controls are presented in Tables VII and VIII. The figures are 24,27 and 22, and 25, 36 and I2, again showing better results in the case of the controls.

Finally the seventh batch of patients with four injections and their controls are shown in Tables IX and X. The figures are 64 , 60 and 40 , and 42,36 and 22 respectively. Here as in the sixth batch the patients were well matched but still the results are better for the controls.

\begin{tabular}{c|c|c|c}
\hline $\begin{array}{c}\text { Patient's } \\
\text { number. }\end{array}$ & $\begin{array}{c}\text { Feb. } \\
1955\end{array}$ & $\begin{array}{c}\text { Sept. } \\
1955\end{array}$ & $\begin{array}{c}\text { March } \\
1957\end{array}$ \\
\cline { 1 - 1 } 3500 & +4 & 19 & 13 \\
3504 & +3 & 16 & 2 \\
3510 & +4 & 21 & 12 \\
3514 & +4 & 15 & 5 \\
3520 & +3 & 9 & 2 \\
3531 & +4 & 22 & 14 \\
3558 & +4 & 23 & 14 \\
3560 & +4 & 24 & 12 \\
3568 & +3 & 16 & 3 \\
3572 & +1 & - & - \\
3580 & +2 & 5 & - \\
\hline
\end{tabular}

Table I

Results of bacteriological tests in the first batch of treated patients.

\begin{tabular}{c|c|c|c}
\hline $\begin{array}{c}\text { Patient's } \\
\text { number. }\end{array}$ & $\begin{array}{c}\text { Feb. } \\
1955\end{array}$ & $\begin{array}{c}\text { Sept. } \\
1955\end{array}$ & $\begin{array}{c}\text { March } \\
1957\end{array}$ \\
\cline { 1 - 2 } 35517 & +3 & 17 & 12 \\
3532 & +2 & 7 & - \\
3543 & +3 & 19 & 5 \\
3551 & +1 & 4 & - \\
3559 & +3 & 9 & - \\
3567 & +2 & - & - \\
3571 & +1 & 1 & - \\
3573 & +4 & 19 & 11 \\
3583 & +4 & 23 & 9 \\
\hline
\end{tabular}

Table II

Results of bacteriological tests in the first batch of controls. 


\begin{tabular}{c|c|c|c}
\hline $\begin{array}{c}\text { Patient's } \\
\text { number. }\end{array}$ & $\begin{array}{c}\text { March } \\
1955\end{array}$ & $\begin{array}{c}\text { Sept. } \\
1955\end{array}$ & $\begin{array}{c}\text { March } \\
1957\end{array}$ \\
\hline 3509 & +4 & 17 & 9 \\
3566 & +3 & 4 & - \\
3587 & +3 & 17 & 6 \\
3591 & +4 & 23 & 16 \\
3597 & +4 & 19 & 10 \\
3601 & +3 & 11 & - \\
\hline
\end{tabular}

Table III

Results of bacteriological tests in the second batch of treated patients.

\begin{tabular}{c|c|c|c}
\hline $\begin{array}{c}\text { Patient's } \\
\text { number. }\end{array}$ & $\begin{array}{c}\text { April } \\
1955\end{array}$ & $\begin{array}{c}\text { Sept. } \\
1955\end{array}$ & $\begin{array}{c}\text { March } \\
1957\end{array}$ \\
\cline { 1 - 2 } 3613 & +4 & 18 & 9 \\
3623 & +4 & 22 & 12 \\
3630 & +4 & 16 & 9 \\
3634 & +4 & 23 & 16 \\
& May & & \\
& 1955 & & \\
3644 & +3 & 18 & 8 \\
3646 & +4 & 24 & 18 \\
& June & & \\
& 1955 & & \\
3659 & +2 & 13 & - \\
3664 & +3 & 18 & 9 \\
\hline
\end{tabular}

Table V

Results of bacteriological tests in the third, fourth and fifth batch of treated patients.

\begin{tabular}{c|c|c|c}
\hline $\begin{array}{c}\text { Patient's } \\
\text { number. }\end{array}$ & $\begin{array}{c}\text { July } \\
1955\end{array}$ & $\begin{array}{c}\text { Sept. } \\
1955\end{array}$ & $\begin{array}{c}\text { March } \\
1957\end{array}$ \\
\hline 3674 & +3 & 21 & 22 \\
3679 & +1 & 6 & - \\
\hline
\end{tabular}

Table VII

Results of bacteriological tests in the sixth batch of treated patients.

\begin{tabular}{c|c|c|c}
\hline $\begin{array}{c}\text { Patient's } \\
\text { number. }\end{array}$ & $\begin{array}{c}\text { August } \\
1955\end{array}$ & $\begin{array}{c}\text { Sept. } \\
1955\end{array}$ & $\begin{array}{c}\text { March } \\
1957\end{array}$ \\
\hline 3686 & +4 & 21 & 18 \\
3688 & +3 & 20 & 6 \\
3691 & +4 & 19 & 16 \\
\hline
\end{tabular}

Table IX

Results of bacteriological tests in the seventh batch of treated patients.

\begin{tabular}{c|c|c|c}
\hline $\begin{array}{c}\text { Patient's } \\
\text { number. }\end{array}$ & $\begin{array}{c}\text { March } \\
1955\end{array}$ & $\begin{array}{c}\text { Sept. } \\
1955\end{array}$ & $\begin{array}{c}\text { March } \\
1957\end{array}$ \\
\cline { 1 - 3 } 3611 & +3 & 17 & 6 \\
& +3 & 12 & - \\
& & & \\
\hline
\end{tabular}

Table IV

Results of bacteriological tests in the second batch of controls.

\begin{tabular}{|c|c|c|c|}
\hline $\begin{array}{l}\text { Patient's } \\
\text { number. }\end{array}$ & $\begin{array}{l}\text { April } \\
1955\end{array}$ & $\begin{array}{l}\text { Sept. } \\
1955\end{array}$ & $\begin{array}{c}\text { March } \\
1957\end{array}$ \\
\hline 3625 & +4 & 20 & 12 \\
\hline 3627 & +2 & 14 & \\
\hline 3629 & +4 & 24 & 21 \\
\hline \multirow[t]{2}{*}{3631} & +2 & 10 & - \\
\hline & $\begin{array}{l}\text { May } \\
1955\end{array}$ & & \\
\hline 3643 & +1 & 2 & - \\
\hline \multirow[t]{2}{*}{3666} & +4 & 23 & 19 \\
\hline & $\begin{array}{l}\text { June } \\
1955\end{array}$ & & \\
\hline 3677 & +1 & 14 & 2 \\
\hline 3680 & +4 & 22 & 10 \\
\hline
\end{tabular}

Table VI

Results of bacteriological tests in the third, fourth and fifth batch of controls.

\begin{tabular}{c|c|c|c}
\hline $\begin{array}{c}\text { Patient's } \\
\text { number. }\end{array}$ & $\begin{array}{c}\text { July } \\
1955\end{array}$ & $\begin{array}{c}\text { Sept. } \\
1955\end{array}$ & $\begin{array}{c}\text { March } \\
1957\end{array}$ \\
\cline { 1 - 3 } 3677 & +1 & 14 & 2 \\
3680 & +4 & 22 & 10 \\
\hline
\end{tabular}

Table VIII

Results of bacteriological tests in the sixth batch of controls.

\begin{tabular}{c|c|c|c}
\hline $\begin{array}{c}\text { Patient's } \\
\text { number. }\end{array}$ & $\begin{array}{c}\text { August } \\
1955\end{array}$ & $\begin{array}{c}\text { Sept. } \\
1955\end{array}$ & $\begin{array}{c}\text { March } \\
1957\end{array}$ \\
\cline { 2 - 4 } 3685 & +3 & 12 & 4 \\
3689 & +4 & 24 & 18 \\
\hline
\end{tabular}

Table X

Results of bacteriological tests in the seventh batch of controls. 
As for the clinincal improvement there is again the difficulty of objective evaluation based on clinical descriptions. I have certainly not observed any marked difference between the treated patients and the controls. It is, however, interesting and perhaps should be put on record that several of the better educated patients who have had long experience of the Settlement have formed the opinion that lepromatous patients who have had the injections of the antigen have definitely improved faster than the general run of patients on sulphones. How far this opinion was influenced by the common belief in greater efficacy of injections compared with drugs taken by mouth I am unable to say.

\section{Conclusions}

The general idea of a treatment of leprosy through the stimulation of a positive allergic response to the bacillus is a tempting one. The question is whether it is really possible artificially to induce such response in a lepromatous patient the essence of whose disease is the inability to create it naturally in spite of the presence of the bacilli in his body. It is known that sulphones only rarely convert the lepromin test in lepromatous patients. Schujman (1956) in his experiments with the BCG vaccine and the Stefansky antigen has found that although it was possible to convert the lepromin reaction in $50 \%$ of his lepromatous subjects such conversion was very short lived. He concluded that induced lepromin reaction in lepromatous cases has no practical value. Blanc claims that he has achieved such conversion by means of the Antigen Marianum in $90 \%$ of his lepromatous patients. I have been unable to confirm it since I have achieved it only in $30 \%$ of my cases. Blanc does not state how permanent the conversion has been. I have not been able to perform the lepromin test in my patients at the second review.

So while on theoretical grounds the idea behind the use of the antigen for the treatment of lepromatous leprosy seems to be sound, on further investigation it does not appear to work so well in practice. On the other hand I do not see any theoretical basis for the use of the antigen in tuberculoid leprosy. The essence of this type of the disease is a strong immunological response. Even if it were possible to make it still stronger it is questionable whether this would be desirable considering the possible damage to the peripheral nerves through an excessive formation of fibrous tissues. We know that a great many of the signs and symptoms in this type of leprosy are caused by this excessive response of the tissues to the bacillus.

However, my aim has been to test Blanc's results in practice. Unfortunately my trial has been cut short and its value is there- 
fore limited. Nevertheless if the results of the injection of antigen were going to be spectacular even 8 months should have been sufficient to indicate them. This is not the case as far as an objective bacteriological test is concerned. As for clinical improvement compared with the controls, the results seem to have been negative as well. Yet I cannot ignore completely the impression gained of certain favourable results reported by the patients, for whatever it is worth.

I have to point out that I was not prepared to go as far as Blanc and deprive my patients of the tried routine treatment with sulphones. In my experience the antigen has been only added to the sulphones. Possibly my patients on the antigen would have improved just as much if they had not taken the sulphones at the same time. With regard to the question as to which treatment is preferable, each injection of the antigen gives a certain amount of general and local reaction, which however harmless is certainly very unpleasant to the patient. Because of that, oral treatment with sulphone seems preferable.

I wish to emphasize again that my trial was rather abortive. For the final evaluation of the treatment with Antigen Marianum one has to wait for the results of other trials like the one being conducted at the present time by Wolcott at Carville.

\section{Summary}

I. A treatment trial with Antigen Marianum was conducted on 55 leprosy patients with 59 controls; all cases received the sulphones.

2. The trial was cut short so that only $5-8$ monthly injections of the antigen was given to the patients.

3. No definite difference was observed in the rate of improvement of patients who received the antigen and sulphones compared with the patients on sulphones alone.

\section{Acknowledgements}

My thanks are due to the patients and members of the staff of the Ossiomo Settlement for their co-operation, to Sister Maric Suzanne for the supply of the antigen, to Dr. S. J. Healy, Area Superintendent Ossiomo Settlement, for permission to review the patients in March, 1957, and to the Director of Medical Services, Western Nigeria, for permission to publish.

\section{REFERENCES}

Blanc, M., et al. (1953). J. des. Sc. Med. de Lille, p. 584.

Blanc, M., and Prost, M. (1955). Int. J. Leprosy, 23, 23.

Schujman, S. (1956). Int. J. Leprosy, 24, 51. 